\title{
Auditor Reputation, Audit Opinion, and Earnings Management: Evidence From French Banking Industry
}

\author{
Manel Hadriche \\ Tunis University, Tunis, Tunisia
}

\begin{abstract}
The aim of this research is to study the impact of auditor reputation and audit opinion on earnings management in French banks. This article used a sample of 162 French banks over the period from 2005 to 2012. By using three different tests (loss-avoidance, just-meeting-or-beating prior year's earnings, and abnormal loan loss provision), the findings of this paper show that both high auditor reputation and qualified audit opinion constrain earnings management to avoid loss or to just meet or beat prior year's earnings in banks. In separate tests related to earnings management through abnormal loan loss provisions, the paper also finds that high auditor reputation constrains earnings management. Qualified audit opinion has a negative but non-significant effect on abnormal loan loss provisions.
\end{abstract}

Keywords: audit opinion, auditor reputation, earnings benchmarks, earnings management, loan loss provisions

\section{Introduction}

The external auditor plays a vital role in the corporate governance mosaic through its influence on promoting the quality of financial reporting. From this optic, an auditor acts as a guardian of the management's behaviour, especially when there is an increased tendency of earnings manipulation. In this context of these challenges, numerous studies have attempted to establish a relationship between audit quality and earnings management for industrial firms (Heninger, 2001; Piot \& Janin, 2005; Gerayli, Yanesari, \& Ma'atoofi, 2011; Memiş \& Çetenak, 2012; Okolie, Izedonmi, \& Enofe, 2013; Okolie, 2014).

These studies exclude banks and financial institutions due to their accounting specificities. Due to the importance of a bank sector in national and international economies, studying factors that affect earnings management in banking industries is needed.

Sanusi (2011) and Brownbridge (1996) have focused on earnings manipulation in banking sector. Sanusi (2011, p. 5) showed that one of the eight reasons for the banking crisis in 2008 was "inadequate disclosure and transparency about financial position of banks". Amongst the terminologies used are accounts manipulation, income smoothing, big bath accounting, creative accounting, and earnings management.

The aim of this research is to study earnings management in banks and specially, we try to examine the relation between auditor reputation and qualified audit opinion and different dimensions of earnings quality of banks. 
Studying earnings management in banks is very important. So, the banking sector is a highly profitable industry, and this high level incites managers to manage and distort earnings. Therefore, banking industry provides an appealing context for examining earnings quality.

In this study, firstly, we focus on the role of Big 4 auditor and qualified audit opinion in contrasting earnings management in banks. A large body of empirical research documents that higher audit quality is associated with Big 4 auditors. Relative to non-Big 4 auditors, Big 4 auditors have greater expertise, resources, and more importantly, market-based incentives (e.g., mitigating the risk of litigation and protecting their reputation capital) to constrain the tendency of their audit clients to engage in aggressive reporting (Teoh \& Wong, 1993; Becker, DeFond, Jiambalvo, \& Subramanyam, 1998; Francis, Maydew, \& Sparks, 1999; Li \& Lin, 2005; Rusmin, 2010). Consequently, we predict that Big 4 auditors constrain earnings management in banks.

Secondly, we examine the effect of qualified audit opinion on earnings management in banks. Many researches show that prior qualified audit opinion about financial information reliability incites managers to reduce earnings management (Gajevszky, 2014; Taktak \& Mbarki, 2014).

We assess earnings quality using three traditional proxies: earnings management to avoid losses, earnings management to just meet or beat the prior year's earnings (Beatty, Ke, \& Petroni, 2002; Altamuro \& Beatty, 2010), and accruals through bank loan loss provisions (Wahlen, 1994; Kanagaretnam, Lobo, \& Yang, 2004; Kanagaretnam, Lim, \& Lobo, 2010).

Using a sample of 162 French banks over the period from 2005 to 2012, we find that both high auditor reputation and qualified audit opinion constrain earnings management to avoid loss and to just meet or beat prior year's earnings in banks. In separate tests related to earnings management through abnormal loan loss provisions, we find that high auditor reputation constrains income-increasing earnings management. Qualified audit opinion has a negative but non-significant effect on abnormal loan loss provisions.

The rest of this paper is organized as follows. The next section develops literature review and hypotheses development. Section 3 describes data. Section 4 explains the measures of earnings management. Section 5 discusses the results, and Section 6 concludes the study.

\section{Literature Review and Hypotheses Development}

\section{Auditor Reputation}

DeAngelo (1981, p. 186) defined audit quality as "the assessment by the market of the joint probability that an auditor discovers simultaneously a significant anomaly in the accounting system of the company and publishes this anomaly or this irregularity".

DeAngelo (1981) argued that auditor size is a proxy for auditor reputation. Big auditors have greater expertise, resources, experiences, and are better able to discover a significant anomaly in financial statements (Rusmin, 2010).

Several studies have focussed on examining the effect of auditor reputation on earnings management (Piot \& Janin, 2005; Sun \& Liu, 2011; Memiş \& Çetenak, 2012; Taktak \& Mbarki, 2014). For industrial firms, Teoh and Wong (1993), Becker et al. (1998), Basu, Hwang, and Jan (2000), Bartov, Gul, and Tsui (2000), Jordan, Clark, and Hames (2010), Brown, Falaschetti, and Orlando (2010), Gerayli et al. (2011), and Okolie et al. (2013) advocated that, relative to small audit firms, big auditors provide higher audit quality and, as such, more aggressively constrain their clients' attempts to manage earnings. So, large auditing offices help improve the quality of financial reports (Hamdan, Mushtaha, \& Al-Sartawi, 2013). 
Additionally, other studies in countries such as France, Belgium, and Greece find that there is no statistically significant difference between the discretionary accruals of firms audited by Big 4 and non-Big 4 auditors (Vander Bauwhede \& Willekens, 2004; Othman \& Zeghal, 2006; Tsipouridou \& Spathis, 2014). For example, Piot and Janin (2005) found no significant association between abnormal accrual and Big 5 auditor. Memiş and Çetenak (2012) proved that Big 4 auditors do not constrain the earnings management incentives in every emerging country.

Auditor reputation may be of higher importance for industries such as banking characterized by high information uncertainty, greater complexity, and difficulty of assessing risk (Autore, Billingsley, \& Schneller, 2009; Kanagaretnam, Lim, \& Lobo, 2014).

Masihi (2013), by presenting an empirical investigation to study the relationship between audit quality and earnings management in Iranian banking industry, found a negative relationship between auditing type and earnings management.

In Tunisian context, Taktak and Mbarki (2014) documented that high auditor reputation does not limit earnings management among major Tunisian banks.

Dabor and Ibadin (2013) demonstrated that to reduce earnings management in Nigerian banks, audit quality must be improved.

Kanagaretnam et al. (2014), by using a sample of banks from 29 countries, found that auditor type constrains income-increasing earnings management.

Thus, we put forward the following hypothesis:

H1: Auditor reputation constrains earnings management.

\section{Auditor Opinion}

The auditor's opinion is the ultimate result of the accountant's investigative work (Hsiao, Lin, \& Hsu, 2010).

Auditors must firstly collect and evaluate audit evidences; secondly, they should express their opinion as to whether the audited financial statements are in accordance with the financial reporting framework. This opinion is inserted in audit report that is communicated to users of the company financial statements (Porter, Simon, \& Hatherly, 2003).

Prior researches find decreasing earnings management in firms involved in bankruptcy and having qualified audit opinion. Rosner (2003) and Charitou, Lambertides, and Trigeorgis (2007) suggested that qualified audit opinion drives managers of distressed firms to be more conservative in their financial reporting.

Etemadi, Dehkordi, and Amirkhani (2013) suggested that under the pressure of audit opinion, distressed firms are compelled to employ conservatism procedures in earnings reporting. Therefore, qualified audit opinion exerts pressure on managers to follow more conservative earnings behaviour.

In a Spanish context and by using a sample of private pre-bankrupt firms, Arnedo, Lizarraga, and Sanchez (2008) tested the relationship between qualified audit opinion and earnings. They divided qualified audit opinions into qualified based on going-concern issues and qualified for other reasons. They documented a negative relationship between earnings management and qualified opinion on going-concern issues (Herbohn \& Ragunathan, 2008). However, they found a positive association between earnings management and qualified opinion for other reasons. They suggested that the negative relationship in going-concern cases is the outcome of auditor conservatism rather than the distressed status of the firm. 
Butler, Leone, and Willenborg (2004) found no evidence that firms receiving modified audit opinions manage earnings more than those receiving clean opinions. In addition, they showed that the documented relation between modified audit opinion and earnings management rests with companies that have going-concern opinions.

Gajevszky (2014) found that the probability to manage earnings to the decrease is related to the issuance of a qualified audit report. Thus, audit opinion is negatively related to discretionary accruals in the case of the Romanian listed companies.

Vichitsarawong and Pornupatham (2015) found that firms receiving modified opinions have lower earnings persistence than firms receiving unqualified opinions, and the degree of earnings persistence varies among types of modifications.

In banking industry, Taktak and Mbarki (2014) showed that modified audit opinions incite managers to reduce earnings management. These results show the importance of audit opinion and especially auditor independence in limiting earnings management practices in banks (Datar, Feltham, \& Hughes, 1991; Lennox, 1999). Thus, we design the following hypothesis:

H2: Prior qualified auditor opinion constrains earnings management.

\section{Data Description}

We obtained financial data for French banks for the period of 2005-2012 from the Bank Scope database. The bank-specific variables were taken from the Bank Scope database and banks' annual reports over a period of eight years (2005-2012). We were left with a panel comprising 162 French banks with 1,296 observations.

\section{Measures of Earnings Management}

We have employed three proxies of earnings management: earnings management to avoid loss, earnings management to just meet or beat prior year's earnings, and abnormal accruals through bank loan loss provisions.

\section{Earnings Management to Avoid Loss or to Just Meet or Beat Prior Year's Earnings}

Beatty et al. (2002), Graham, Harvey, and Rajgopal (2005), Altamuro and Beatty (2010), and Kanagaretnam et al. $(2010 ; 2011 ; 2014)$ found that managers can manage earnings to just meet or beat prior period's earnings or to avoid loss (Burgstahler \& Dichev, 1997; Kanagaretnam et al., 2010; 2014).

We examined how high auditor reputation and qualified audit opinion constrain the two earnings benchmarks: loss-avoidance (LOSS_AVOID) and just-meeting-or-beating prior year's earnings (JMBE).

We looked at several bank-specific variables that may explain earnings management. These include: bank size, growth, and leverage.

We estimated the following logit model:

$$
\text { BENCHMARK }=\alpha_{0}+\alpha_{1} B I G 4+\alpha_{2} O P I N+\alpha_{3} S I Z E+\alpha_{4} G R O W T H+\alpha_{5} L O A N S+\alpha_{6} L E V+\varepsilon
$$

where:

BENCHMARK: Earnings management indicators (LOSS_AVOID or JMBE);

LOSS_AVOID: An indicator variable that takes 1 if the bank has a small return on asset (ROA) in the interval between 0 and 0.002 , and 0 if otherwise;

$J M B E$ : An indicator variable that takes 1 if the bank has a change in ROA from year $t-1$ to year $t$ in the interval between 0 and 0.0005 , and 0 if otherwise; 
BIG4: An indicator variable that takes 1 if the auditor is a Big 4 auditor, and 0 if otherwise;

$O P I N$ : An indicator variable that takes 1 if there is a qualified opinion in year $t-1$, and 0 if otherwise;

SIZE: A variable measured by log of total assets;

GROWTH: The growth in total assets from the beginning to the end of year $t$;

LOANS: Total loans scaled by total assets at the beginning of year $t$;

$L E V$ : Total equity divided by total assets at beginning of year $t$.

If higher auditor reputation and qualified audit opinion reduce earnings management to avoid loss or to just meet or beat prior year's earnings, the coefficients of BIG4 and $O P I N$ will be negative.

\section{Earnings Management Through Abnormal Loan Loss Provisions}

Banks use loan loss provisions to adjust their loan loss reserves to reflect expected future losses on their loan portfolios. These provisions can have significant impacts on the reported earnings, as they are a large accrual for banks.

Loan loss provision is the largest and the most important accrual for banks (Ahmed, Takeda, \& Thomas, 1999; Kanagaretnam et al., 2014). We used three steps to examine the relation between auditor reputation and earnings management through loan loss provisions.

The first step consists on estimating the coefficients of the model that includes the normal part of provisions over the period of 2005-2012. The model is as follows:

$$
L L P_{i t}=\beta_{0}+\beta_{1} L L A_{i t-1}+\beta_{2} L C O_{i t}+\beta_{3} C_{H L O A N S_{i t}}+\beta_{4} L O A N S_{i t}+\beta_{5} N P L_{i t}+\varepsilon_{i t}
$$

where:

$L L P_{i t}:$ The loan loss provisions of the bank $i$ at date $t$;

$L L A_{i t-1}$ : The loan loss allowance of the bank $i$ at date $t-1$;

$L C O_{i t}$ : Net loan charge-offs of the bank $i$ at time $t$;

CHLOANS $i t$ : The change in total loans outstanding of the bank $i$ at time $t$;

$\operatorname{LOANS}_{i t}$ : Total loan of the bank $i$ at time $t$;

$N P L_{i t}$ : Non-performing loans of the bank $i$ at time $t$;

$\varepsilon$ : The error term, which represents the discretionary portion of loan loss provisions of bank $i$ in period $t$.

The expected signs of the coefficients on these variables are as follows. Non-performing loans are likely to positively affect provisions for loan losses. An increase in non-performing loans at the beginning of the year leads banks to increase the loan loss provisions. The sign of the change in total loans is also expected to be positive, since an increase in loans may result in an increase in loan loss provisions due to doubtful loans.

The second step consists on estimating the non-discretionary component of loan loss provisions. The estimated coefficients $\beta_{0}, \beta_{1}, \beta_{2}, \beta_{3}, \beta_{4}$, and $\beta_{5}$ are used to calculate the predicted values of loan loss provisions $\left(L L P N D_{i t}\right)$ over the period of 2005-2012.

The last step consists on calculating the discretionary provisions (ALLP) given as the difference between loan loss provisions (LLP) and the non-discretionary loan loss provisions (LLPND).

In the second stage, we tested the relationship between auditor reputation and qualified audit opinion and the absolute value of ALLP.

As control variables, we used the following factors that can affect abnormal accruals: firm size, growth, and leverage (Ashbaugh, LaFond, \& Mayhew, 2003).

Our model is as follows: 


$$
A L L P=\beta_{0}+\beta_{1} B I G 4+\beta_{2} O P I N+\beta_{3} S I Z E+\beta_{4} G R O W T H+\beta_{5} L E V+\varepsilon
$$

\section{Empirical Results}

Firstly, we presented the results of the earnings management to avoid loss or to just meet or beat prior year's earnings; secondly, we reported the results of earnings management through abnormal bank loan loss provisions.

\section{Earnings Management to Avoid Loss or to Just Meet or Beat Prior Year's Earnings}

We presented the results of the earnings management to avoid loss or just meet or beat prior year's earnings in Table 1. Descriptive statistics are presented in Panel A. On average, $11 \%$ of our sample banks just avoided reporting a loss and $12 \%$ of our sample banks just meet or beat prior year's earnings. In addition, $73 \%$ of the banks are audited by Big 4 auditors. Finally, qualified audit opinions represent about $79 \%$ over the study period.

Panel B reports the correlations among bank-specific variables. As shown in Panel B, there is a negative association between Big 4 auditors and loss-avoidance and just-meeting-or-beating prior year's earnings. There is also a negative association between audit opinion and loss-avoidance and just-meeting-or-beating prior year's earnings. This means that the argument that high auditor reputation and prior qualified audit opinion reduce earnings management is proved.

These results are interesting, but we rely on the multivariate analysis that includes all other factors likely to affect earnings management for making inferences.

Table 1

Descriptive Statistics and Correlations for Earnings Benchmark Test

\begin{tabular}{llll}
\hline \multicolumn{4}{c}{ Panel A: Descriptive statistics } \\
\hline Variable & Mean & Median & Std. dev. \\
\hline LOSS_AVOID & 0.116129 & 0 & 0.3205865 \\
JMBE & 0.1262458 & 0 & 0.3324024 \\
BIG4 & 0.7348837 & 1 & 0.4415663 \\
OPIN & 0.7986111 & 1 & 0.4011927 \\
SIZE & 6.486171 & 6.267851 & 1.001572 \\
GROWTH & 0.1805141 & 0.0679428 & 0.9749477 \\
LOANS & 0.5270909 & 0.5800781 & 0.2827715 \\
LEV & 12.43662 & 7.553 & 15.41796 \\
\hline
\end{tabular}

Panel B: Correlations

\begin{tabular}{lcccccccc}
\hline Variable & LOSS_AVOID & JMBE & BIG4 & OPIN & SIZE & GROWTH & LOANS & LEV \\
\hline LOSS_AVOID & 1 & & & & & & & \\
JMBE & -0.0943 & 1 & & & & & & \\
BIG4 & -0.1276 & -0.1291 & 1 & & & & & \\
OPIN & -0.2801 & -0.2072 & 0.0919 & 1 & & & \\
SIZE & 0.1919 & -0.0693 & -0.1184 & -0.0245 & 1 & & & \\
GROWTH & -0.0323 & -0.0077 & 0.0057 & 0.0494 & -0.0141 & 1 & & \\
LOANS & 0.0136 & 0.0390 & -0.0956 & -0.0475 & -0.0543 & -0.0319 & 1 & \\
LEV & -0.1431 & 0.0087 & 0.0390 & 0.0456 & -0.4416 & -0.0108 & -0.3072 & 1 \\
\hline
\end{tabular}

Notes. LOSS_AVOID is an indicator variable that takes 1 if the bank has a small ROA in the interval between 0 and 0.002 , and 0 if otherwise; $J M B E$ is an indicator variable that takes 1 if the bank has a change in ROA from year $t-1$ to year $t$ in the interval between 0 and 0.0005 , and 0 if otherwise; $B I G 4$ is an indicator variable that takes 1 if the auditor is a Big 4 auditor, and 0 if otherwise; OPIN is an indicator variable that takes 1 if there is a qualified opinion in year $t-1$, and 0 if otherwise; SIZE is the log of total assets; GROWTH is the growth in total assets from the beginning to the end of the year; LOANS is total loans scaled by total assets at the beginning of the year; $L E V$ is total equity divided by total assets at the beginning of the year. 
Table 2 reports the results of the logistic regressions. The first three columns present the results for the loss-avoidance tests. In Model (1), we have included only auditor reputation. In Model (2), we have included only audit opinion proxied by whether the prior audit report presents a qualified opinion (reservation). In Model (3), we have included both the two variables: auditor reputation and audit opinion.

In Model (1), the coefficient of BIG4 is negative and significant (at the $1 \%$ level), indicating the confirmation of $\mathrm{H} 1$ that high auditor reputation constrains earnings management to avoid loss in banks. In Model (2) and for audit opinion, we also find a negative and significant (at the $1 \%$ level) coefficient estimate for $O P I N$ indicating the confirmation of $\mathrm{H} 2$. When we include both auditor reputation and audit opinion in Model (3), the coefficients of BIG4 and OPIN maintain significance at $5 \%$ and $1 \%$ levels; these results indicate that high auditor reputation and qualified audit opinion constrain earnings management to avoid loss in banks.

Table 2

Regression Results for the Loss-Avoidance and Just-Meeting-or-Beating Prior Year's Earnings Benchmark Tests

\begin{tabular}{|c|c|c|c|c|c|c|c|}
\hline \multirow{2}{*}{ Variable } & \multirow{2}{*}{ Coeff. } & \multicolumn{3}{|c|}{ Loss-avoidance test } & \multicolumn{3}{|c|}{ Just-meeting-or-beating prior year's earnings } \\
\hline & & Model (1) & Model (2) & Model (3) & Model (1) & Model (2) & Model (3) \\
\hline Intercept & $\alpha_{0}$ & $\begin{array}{c}-4.299 \\
(-1.97)^{* *}\end{array}$ & $\begin{array}{c}-4.030 \\
(-2.00)^{* *}\end{array}$ & $\begin{array}{r}-3.151 \\
(-1.53) \\
\end{array}$ & $\begin{array}{c}1.188 \\
(0.78)\end{array}$ & $\begin{array}{c}0.824 \\
(0.55)\end{array}$ & $\begin{array}{c}2.258 \\
(1.34)\end{array}$ \\
\hline$B I G 4$ & $\alpha_{1}$ & $\begin{array}{l}-1.102 \\
(-2.77)^{* * *}\end{array}$ & & $\begin{array}{l}-0.898 \\
(-2.29)^{* *}\end{array}$ & $\begin{array}{l}-1.221 \\
(-3.55)^{* * *}\end{array}$ & & $\begin{array}{l}-1.216 \\
(-3.32)^{* * *}\end{array}$ \\
\hline OPIN & $\alpha_{2}$ & & $\begin{array}{l}-1.679 \\
(-5.01)^{* * *}\end{array}$ & $\begin{array}{l}-1.615 \\
(-4.77)^{* * *}\end{array}$ & & $\begin{array}{l}-1.478 \\
(-4.77)^{* * *}\end{array}$ & $\begin{array}{l}-1.517 \\
(-4.63)^{* * *}\end{array}$ \\
\hline SIZE & $\alpha_{3}$ & $\begin{array}{c}0.457 \\
(1.75)^{*} \\
\end{array}$ & $\begin{array}{c}0.475 \\
(1.97)^{* *} \\
\end{array}$ & $\begin{array}{c}0.442 \\
(1.81)^{*} \\
\end{array}$ & $\begin{array}{c}-0.391 \\
(-1.92)^{*} \\
\end{array}$ & $\begin{array}{c}-0.343 \\
(-1.71)^{*} \\
\end{array}$ & $\begin{array}{c}-0.419 \\
(-1.89)^{*}\end{array}$ \\
\hline GROWTH & $\alpha_{4}$ & $\begin{array}{c}-0.731 \\
(-1.13) \\
\end{array}$ & $\begin{array}{c}-0.594 \\
(-0.89) \\
\end{array}$ & $\begin{array}{r}-0.625 \\
(-0.93)\end{array}$ & $\begin{array}{c}-0.011 \\
(-0.07)\end{array}$ & $\begin{array}{c}0.024 \\
(0.16) \\
\end{array}$ & $\begin{array}{r}0.043 \\
(0.28) \\
\end{array}$ \\
\hline$L O A N S$ & $\alpha_{5}$ & $\begin{array}{r}-0.009 \\
(-0.11) \\
\end{array}$ & $\begin{array}{c}-0.082 \\
(-0.10) \\
\end{array}$ & $\begin{array}{r}-0.166 \\
(-0.20) \\
\end{array}$ & $\begin{array}{r}0.120 \\
(0.20) \\
\end{array}$ & $\begin{array}{r}0.320 \\
(0.53) \\
\end{array}$ & $\begin{array}{r}0.079 \\
(0.12) \\
\end{array}$ \\
\hline$L E V$ & $\alpha_{6}$ & $\begin{array}{c}-0.076 \\
(-1.97)^{* *}\end{array}$ & $\begin{array}{c}-0.071 \\
(-1.92)^{*}\end{array}$ & $\begin{array}{c}-0.073 \\
(-1.95)^{*}\end{array}$ & $\begin{array}{c}-0.006 \\
(-0.43)\end{array}$ & $\begin{array}{c}0.0001 \\
(0.01)\end{array}$ & $\begin{array}{c}-0.003 \\
(-0.22)\end{array}$ \\
\hline Likelihood ratio & & $-190.177^{* * *}$ & $-181.778^{* * *}$ & $-179.066^{*}$ & $-214.851^{* *}$ & $-211.115^{* * *}$ & $-203.093^{* * *}$ \\
\hline
\end{tabular}

Notes. The regression model is: BENCHMARK $=\alpha_{0}+\alpha_{1} B I G 4+\alpha_{2}$ OPIN $+\alpha_{3} S I Z E+\alpha_{4}$ GROWTH $+\alpha_{5} L O A N S+\alpha_{6} L E V+\varepsilon$, where BENCHMARK is defined as LOSS_AVOID or JMBE. For each variable, we report the regression coefficient, followed by the $t$-statistic in parentheses. ${ }^{*}:$ Significance at $10 \%$ level (two-tailed); ${ }^{* *}$ : Significance at $5 \%$ level (two-tailed); ${ }^{* * *}$ : Significance at $1 \%$ level (two-tailed).

The next three columns provide the results of the JMBE tests. In Model (1), the coefficient of BIG4 is negative and significant at the $1 \%$ level. In Model (2), the coefficient of OPIN is negative and significant at the $1 \%$ level. In Model (3), where we include both auditor reputation and audit opinion, the coefficients of $B I G 4$ and $O P I N$ maintain significance at the $1 \%$ level. These results indicate that high auditor reputation and qualified audit opinion constrain earnings management to meet or beat the prior year's earnings in banks.

We conclude that high auditor reputation and qualified audit opinion help to constrain earnings management to avoid loss or to just meet or beat prior year's earnings.

\section{Earnings Management Through Abnormal Loan Loss Provisions}

The results for the abnormal loan loss provisions tests are given in Tables 3-5. Table 3 presents the results of the stage-one regression in estimating abnormal loan loss provisions. As shown, $L L A$ is negatively associated with $L L P$, so an increase in $L L A$ requires a decrease in $L L P$. $L C O, L O A N S$, and $N P L$ are positively associated with $L L P$, as reported in Kanagaretnam, Lobo, and Yang (2004). 
The residuals from Equation (2) represent the abnormal loan loss provisions.

Table 3

Stage-One Regression in Estimating Abnormal Loan Loss Provisions

\begin{tabular}{|c|c|c|}
\hline Variable & Coeff. & Estimate \\
\hline Intercept & $\beta_{0}$ & $\begin{array}{r}-0.107 \\
(-1.59)\end{array}$ \\
\hline$L L A$ & $\beta_{1}$ & $\begin{array}{c}-0.486 \\
(-0.31) \\
\end{array}$ \\
\hline$L C O$ & $\beta_{2}$ & $\begin{array}{c}0.191 \\
(1.55)^{*}\end{array}$ \\
\hline CHLOANS & $\beta_{3}$ & $\begin{array}{l}-0.0001 \\
(-0.03)\end{array}$ \\
\hline LOANS & $\beta_{4}$ & $\begin{array}{r}0.127 \\
(1.04) \\
\end{array}$ \\
\hline$N P L$ & $\beta_{5}$ & $\begin{array}{c}0.198 \\
(17.86)^{* * *}\end{array}$ \\
\hline
\end{tabular}

Notes. We report the results for the following stage-one regression model: $L L P_{i t}=\beta_{0}+\beta_{1} L L A_{i t-1}+\beta_{2} L C O_{i t}+\beta_{3} C H L O A N S_{i t}+$ $\beta_{4} L O A N S_{i t}+\beta_{5} N P L_{i t}+\varepsilon_{i t}$, where $L L P$ is the provisions for loan losses; $L L A$ is the beginning loan loss allowance; $L C O$ is net loan charge-offs; CHLOANS is the change in total loans outstanding; LOANS is total loans outstanding; NPL is the non-performing loans. These variables are deflated by beginning total assets. For each variable, we report the regression coefficient, followed by the $t$-statistic in parentheses. ${ }^{*}:$ Significance at $10 \%$ level (two-tailed); ${ }^{* *}$ : Significance at $5 \%$ level (two-tailed); ${ }^{* * *}:$ Significance at $1 \%$ level (two-tailed).

Table 4 presents the regression results for the absolute value of ALLP values.

Table 4

Relationship Between Absolute Value of Income-Increasing ALLP and Auditor Reputation and Audit Opinion

\begin{tabular}{|c|c|c|c|c|}
\hline Variable & Coeff. & Model (1) & Model (2) & Model (3) \\
\hline Intercept & $\gamma_{0}$ & $\begin{array}{c}0.374 \\
(6.73)^{* * *}\end{array}$ & $\begin{array}{c}0.329 \\
(6.16)^{* * *}\end{array}$ & $\begin{array}{l}0.381 \\
(6.77)^{* * *}\end{array}$ \\
\hline$B I G 4$ & $\gamma_{1}$ & $\begin{array}{l}-0.043 \\
(-2.75)^{* * *}\end{array}$ & & $\begin{array}{l}-0.042 \\
(-2.69)^{* * *}\end{array}$ \\
\hline OPIN & $\gamma_{2}$ & & $\begin{array}{c}-0.014 \\
(-0.94) \\
\end{array}$ & $\begin{array}{l}-0.010 \\
(-0.70)\end{array}$ \\
\hline SIZE & $\gamma_{3}$ & $\begin{array}{l}-0.041 \\
(-5.54)^{* * *}\end{array}$ & $\begin{array}{c}-0.038 \\
(-5.14)^{* * *}\end{array}$ & $\begin{array}{c}-0.041 \\
(-5.54)^{* * *}\end{array}$ \\
\hline GROWTH & $\gamma_{4}$ & $\begin{array}{c}-0.004 \\
(-0.52)\end{array}$ & $\begin{array}{c}-0.003 \\
(-0.40)\end{array}$ & $\begin{array}{c}-0.004 \\
(-0.47)\end{array}$ \\
\hline$L E V$ & $\gamma_{5}$ & $\begin{array}{l}-0.0002 \\
(-0.53) \\
\end{array}$ & $\begin{array}{l}-0.0001 \\
(-0.34) \\
\end{array}$ & $\begin{array}{l}-0.0002 \\
(-0.50) \\
\end{array}$ \\
\hline
\end{tabular}

Notes. The table reports the results for the following stage-two regression model: The dependent variable is the absolute value of the negative (income-increasing) abnormal loan loss provisions. The definitions for the variables are provided in notes of Tables 1 and 3. For each variable, we report the regression coefficient, followed by the $t$-statistic in parentheses. * : Significance at $10 \%$ level (two-tailed); ${ }^{* *}$ : Significance at $5 \%$ level (two-tailed); ${ }^{* * *}$ : Significance at $1 \%$ level (two-tailed).

In Model (1), the coefficient of auditor reputation measured by $B I G 4$ is negative and significant at the $1 \%$ level. In Model (2) where we have included only audit opinion measured by OPIN, the coefficient is negative but no longer significant at conventional levels. In Model (3) where we have included in the model both auditor reputation and audit opinion, the coefficient of BIG4 is significant at the $1 \%$ level, but the coefficient of OPIN is negative but no longer significant at conventional levels. 
These results indicate that high auditor reputation constrains earnings management through ALLP by banks. We conclude that qualified audit opinion has a negative but non-significant effect on income-increasing earnings management.

Kanagaretnam et al. (2010) proved that the most likely area to find earnings management in banks is by testing the interactions between LOSS_AVOID and JMBE and BIG4 and OPIN. For this reason, we add LOSS_AVOID and JMBE and their interactions with BIG4 and OPIN to model.

Table 5 reports the regression results for this expanded model. In Model (1), the coefficient of $B I G 4$ is negative and significant at the $1 \%$ level. This is consistent with our hypothesis that the influence of auditor reputation is more important in constraining earnings management through ALLP when banks have incentives for benchmark beating. In Model (2), the coefficient of OPIN is still non-significant, but the coefficient of OPIN*LOSS_AVOID is negative and significant at the $5 \%$ level. In Model (3), the coefficient of BIG4 is negative and significant at the $5 \%$ level. The coefficient of $O P I N$ is still non-significant, but the coefficient of OPIN*LOSS_AVOID is negative and significant at the $5 \%$ level.

Table 5

Association Between Absolute Value of Income-Increasing ALLP, Loss-Avoidance, Just-Meeting-or-Beating Prior Year's Earnings, and Auditor Reputation and Audit Opinion

\begin{tabular}{|c|c|c|c|c|}
\hline Variable & Coeff. & Model (1) & Model (2) & Model (3) \\
\hline Intercept & $\gamma_{0}$ & $\begin{array}{l}0.378 \\
(6.53)^{* * *}\end{array}$ & $\begin{array}{c}0.304 \\
(5.38)^{* * *}\end{array}$ & $\begin{array}{c}0.363 \\
(6.02)^{* * *}\end{array}$ \\
\hline$B I G 4$ & $\gamma_{1}$ & $\begin{array}{l}-0.050 \\
(-2.56)^{* * *}\end{array}$ & & $\begin{array}{l}-0.050 \\
(-2.60)^{* *}\end{array}$ \\
\hline OPIN & $\gamma_{2}$ & & $\begin{array}{c}0.004 \\
(0.22)\end{array}$ & $\begin{array}{c}0.008 \\
(0.39)\end{array}$ \\
\hline SIZE & $\gamma_{3}$ & $\begin{array}{l}-0.041 \\
(-5.41)^{* * *}\end{array}$ & $\begin{array}{l}-0.036 \\
(-4.86)^{* * *}\end{array}$ & $\begin{array}{l}-0.04 \\
(-5.23)^{* * *}\end{array}$ \\
\hline GROWTH & $\gamma_{4}$ & $\begin{array}{c}-0.004 \\
(-0.53)\end{array}$ & $\begin{array}{c}-0.003 \\
(-0.43)\end{array}$ & $\begin{array}{c}-0.005 \\
(-0.55) \\
\end{array}$ \\
\hline$L E V$ & $\gamma_{5}$ & $\begin{array}{l}-0.0002 \\
(-0.52) \\
\end{array}$ & $\begin{array}{c}-0.0001 \\
(-0.29) \\
\end{array}$ & $\begin{array}{l}-0.0002 \\
(-0.47)\end{array}$ \\
\hline LOSS_AVOID & $\gamma_{6}$ & $\begin{array}{c}0.006 \\
(0.18)\end{array}$ & $\begin{array}{c}0.048 \\
(1.49)^{*}\end{array}$ & $\begin{array}{c}0.040 \\
(0.98)\end{array}$ \\
\hline$J M B E$ & $\gamma_{7}$ & $\begin{array}{c}-0.034 \\
(-0.98)\end{array}$ & $\begin{array}{c}0.008 \\
(0.25)\end{array}$ & $\begin{array}{c}-0.029 \\
(-0.64)\end{array}$ \\
\hline BIG4*LOSS_AVOID & $\gamma_{8}$ & $\begin{array}{c}-0.017 \\
(-0.41) \\
\end{array}$ & & $\begin{array}{l}0.0002 \\
(0.00)\end{array}$ \\
\hline$B I G 4 * J M B E$ & $\gamma_{9}$ & $\begin{array}{c}0.048 \\
(1.10)\end{array}$ & & $\begin{array}{c}0.051 \\
(1.15)\end{array}$ \\
\hline$O P I N^{*} L O S S \_A V O I D$ & $\gamma_{10}$ & & $\begin{array}{c}-0.098 \\
(-2.22)^{* *}\end{array}$ & $\begin{array}{c}-0.092 \\
(-2.06)^{* *}\end{array}$ \\
\hline$O P I N^{*} J M B E$ & $\gamma_{11}$ & & $\begin{array}{c}-0.008 \\
(-0.19)\end{array}$ & $\begin{array}{r}-0.009 \\
(-0.21)\end{array}$ \\
\hline
\end{tabular}

Notes. The table reports the results for the following stage-two regression model: For each variable, we report the regression coefficient, followed by the $t$-statistic in parentheses. ": Significance at $10 \%$ level (two-tailed); ${ }^{* *}$ : Significance at $5 \%$ level (two-tailed); ${ }^{* * *}$ : Significance at $1 \%$ level (two-tailed).

We can conclude and in tandem with our theoretical expectation, auditors' high reputation and qualified audit opinion help to constrain earnings benchmarks undertaken by banks. So, Big 4 auditors may constrain earnings management by minimizing the propensity of corporate managers to manage earnings through the inflation of discretionary accruals of banks in France. Moreover, firms with qualified audit reports tend to have lowered earnings management benchmarks; this phenomenon signals the conservatism of managers. 
For income-increasing earnings management, results confirm our hypothesis that high auditor reputation constrains earnings management by banks. We also conclude that qualified audit opinion has a negative but non-significant effect on income-increasing earnings management.

For the influence of auditor reputation on reducing earnings management through ALLP when banks have incentives for benchmark beating, results show that the coefficient of $B I G 4$ is still negative and significant at the $5 \%$ level, but the coefficient of OPIN is still non-significant and the coefficient of OPIN*LOSS_AVOID is negative and significant at the $5 \%$ level.

As for the control variables, the coefficient of bank size is positive and significant for loss-avoidance test reflecting that larger firms tend to have higher earnings management, but it is negative and significant for just-meeting-or-beating prior year's earnings and abnormal loan loss provisions test, so bigger banks have lesser tendency to manage earnings. Thus, we tend to have more confidence in bigger banks because of the safety of the deposits.

All other control variables do not have a significant effect on earnings management.

\section{Conclusion}

The objective of this research is to provide evidence on the implications of auditing for banks' earnings quality. It aims to test the effect of auditor reputation and qualified audit opinion on earnings management in the French banking industry. To do this, we used a sample of 162 French banks over the period of 2005-2012.

We hypothesize that high auditor reputation and qualified audit opinion would constrain earnings management in banks. The results for the earnings management to avoid loss or to just meet or beat prior year's earnings indicate that high auditor reputation and qualified auditor opinion help to constrain earnings management undertaken by banks.

For earnings management through ALLP, we have found that only high auditor reputation has a significant impact on constraining income-increasing earnings management. Our results show the importance of high auditor reputation in constraining income-increasing earnings management in a highly regulated industry such as French banking.

This study contributes to knowledge by integrating two streams of research in earnings management and audit quality which has been desperate and incongruent in several economies.

This study adds to existing knowledge on earnings management by showing that when the quality of audit is high, corporate managers in banks will shift away from managing discretionary accruals for fear of detection by the auditors.

These results have implications for both stakeholders and policymakers. Firstly, our study documents an important external mechanism, "auditor reputation", which can constrain earnings management in French banks. Therefore, in order to reduce earnings management, banks must choose Big 4 auditors. Secondly, audit modifications reflect different degrees of problematic issues in banks, resulting in different impacts on earnings persistence. Thus, policymakers and regulators should emphasize the importance of using auditors' reports. Strengthened enforcement by regulators makes individual auditors more aware of reputation risk and more likely to express appropriate audit opinions. 


\section{References}

Ahmed, A. S., Takeda, C., \& Thomas, S. (1999). Bank loan loss provisions: A reexamination of capital management, earnings management, and signaling effects. Journal of Accounting and Economics, 28(1), 1-25.

Altamuro, J., \& Beatty, A. (2010). How does internal control regulation affect financial reporting? Journal of Accounting and Economics, 49(1-2), 58-74.

Arnedo, L., Lizarraga, F., \& Sanchez, S. (2008). Discretionary accruals and auditor behaviour in code-law contexts: An application to failing Spanish firms. European Accounting Review, 17(4), 641-666.

Ashbaugh, H., LaFond, R., \& Mayhew, B. W. (2003). Do nonaudit services compromise auditor independence? Further evidence. The Accounting Review, 78(3), 611-639.

Autore, D. M., Billingsley, R. S., \& Schneller, M. I. (2009). Information uncertainty and auditor reputation. Journal of Banking and Finance, 33(2), 183-192.

Bartov, E., Gul, F. A., \& Tsui, J. S. L. (2000). Discretionary-accruals models and audit qualifications. Journal of Accounting and Economics, 30(3), 421-452.

Basu, S., Hwang, L. S., \& Jan, C. L. (2000). Differences in conservatism between big eight and non-big eight auditors. Working Paper, City University of New York and California State University.

Beatty, A. L., Ke, B., \& Petroni, K. R. (2002). Earnings management to avoid earnings declines across publicly and privately held banks. The Accounting Review, 77(3), 547-570.

Becker, C. L., DeFond, M. L., Jiambalvo, J., \& Subramanyam, K. R. (1998). The effect of audit quality on earnings management. Contemporary Accounting Research, 15(1), 1-24.

Brown, J. R., Falaschetti, D., \& Orlando, M. J. (2010). Auditor independence and earnings quality: Evidence for market discipline vs. Sarbanes-Oxley proscriptions. American Law and Economics Review, 12(1), 39-68.

Brownbridge, M. (1996). The impact of public policy on the banking system in Nigeria. Zaria, Nigeria: Institute of Development Studies.

Burgstahler, D., \& Dichev, I. (1997). Earnings management to avoid earnings decreases and losses. Journal of Accounting and Economics, 24(1), 99-126.

Butler, M., Leone, A. J., \& Willenborg, M. (2004). An empirical analysis of auditor reporting and its association with abnormal accruals. Journal of Accounting and Economics, 37(2), 139-165.

Charitou, A., Lambertides, N., \& Trigeorgis, L. (2007). Earnings behaviour of financially distressed firms: The role of institutional ownership. Abacus, 43(3), 271-296.

Dabor, E. L., \& Ibadin, P. O. (2013). An evaluation of the implications of earnings management determinants in the banking industry: The case of Nigeria. African Journal of Social Sciences, 3(3), 118-129.

Datar, S. M., Feltham, G. A., \& Hughes, J. S. (1991). The role of audits and audit quality in valuing new issues. Journal of Accounting and Economics, 14(1), 3-49.

DeAngelo, L. E. (1981). Auditor size and audit quality. Journal of Accounting and Economics, 3(3), 183-199.

Etemadi, H., Dehkordi, H. F., \& Amirkhani, K. (2013). Effect of auditor opinion on discretionary accruals behavior of distressed firms: Empirical evidences from Iran. African Journal of Business Management, 7(20), 1956-1965.

Francis, J. R., Maydew, E. L., \& Sparks, H. C. (1999). The role of Big 6 auditors in the credible reporting of accruals. Auditing: A Journal of Practice and Theory, 18(2), 17-34.

Gajevszky, A. (2014). The impact of auditor's opinion on earnings management: Evidence from Romania. Network Intelligence Studies, 2(3), 61-73.

Gerayli, M. S., Yanesari, A. M., \& Ma'atoofi, A. R. (2011). Impact of audit quality on earnings management: Evidence from Iran. International Research Journal of Finance and Economics, 66, 77-84.

Graham, J. R., Harvey, C. R., \& Rajgopal, S. (2005). The economic implications of corporate financial reporting. Working Paper, Duke, NBER, and University of Washington, Seattle.

Hamdan, A. M. M., Mushtaha, S. M. S., \& Al-Sartawi, A. A. M. (2013). The audit committee characteristics and earnings quality: Evidence from Jordan. Australasian Accounting, Business, and Finance Journal, 7(4), 51-80.

Heninger, W. G. (2001). The association between auditor litigation and abnormal accruals. The Accounting Review, 76(1), 111-126.

Herbohn, K., \& Ragunathan, V. (2008). Auditor reporting and earnings management: Some additional evidence. Accounting and Finance, 48(4), 575-601. 
Hsiao, F. H., Lin, S. H., \& Hsu, A. C. (2010). Earnings management, corporate governance, and auditor's opinions: A financial distress prediction model. Investment Management and Financial Innovations, 7(3), 29-40.

Jordan, C. E., Clark, S. J., \& Hames, C. C. (2010). The impact of audit quality on earnings management to achieve user reference points in EPS. The Journal of Applied Business Research, 26(1), 19-30.

Kanagaretnam, K., Lim, C. Y., \& Lobo, G. J. (2010). Auditor reputation and earnings management: International evidence from the banking industry. Journal of Banking and Finance, 34(10), 2318-2327.

Kanagaretnam, K., Lim, C. Y., \& Lobo, G. J. (2011). Effects of national culture on earnings quality of banks. Journal of International Business Studies, 42, 853-874.

Kanagaretnam, K., Lim, C. Y., \& Lobo, G. J. (2014). Effects of international institutional factors on earnings quality of banks. Journal of Banking and Finance, 39, 87-106.

Kanagaretnam, K., Lobo, G. J., \& Yang, D. H. (2004). Joint tests of signaling and income smoothing through bank loan loss provisions. Contemporary Accounting Research, 21(4), 843-884.

Lennox, C. S. (1999). Audit quality and auditor size: An evaluation of reputation and deep pockets hypotheses. Journal of Business Finance and Accounting, 26(7-8), 779-805.

Li, J., \& Lin, J. (2005). The relationship between earnings management and audit quality. Journal of Accounting and Finance Research, 12(1), 1-11.

Masihi, M. (2013). A study on relationship between audit quality and earnings management in Iranian banking industry. Management Science Letters, 3(12), 2971-2976.

Memiş, M. Ü., \& Çetenak, E. H. (2012). Earnings management, audit quality, and legal environment: An international comparison. International Journal of Economics and Financial Issues, 2(4), 460-469.

Okolie, A. O. (2014). Accrual-based earnings management, corporate policies, and managerial decisions of quoted companies in Nigeria. Research Journal of Finance and Accounting, 5(2), 1-14.

Okolie, A. O., Izedonmi, F. O. I., \& Enofe, A. O. (2013). Audit quality and accrual-based earnings management of quoted companies in Nigeria. IOSR Journal of Economics and Finance, 2(2), 7-16.

Othman, H. B., \& Zeghal, D. (2006). A study of earnings-management motives in the Anglo-American and Euro-Continental accounting models: The Canadian and French cases. The International Journal of Accounting, 41(4), 406-435.

Piot, C., \& Janin, R. (2005). Audit quality and earnings management in France. Working Paper, IUT GEA, Piere Mendes France University, France.

Porter, B., Simon, J., \& Hatherly, D. (2003). Principles of external auditing (2nd ed.). England: John Wiley \& Sons.

Rosner, R. L. (2003). Earnings manipulation in failing firms. Contemporary Accounting Research, 20(2), 361-408.

Rusmin, R. (2010). Auditor quality and earnings management: Singaporean evidence. Managerial Auditing Journal, 25(7), 618-638.

Sanusi, L. S. (2011). Banks in Nigeria and national economic development: A critical review. Keynote address at the Seminar on "Becoming an Economic Driver While Applying Banking Regulations" organized by the Canadian High Commission in joint collaboration with the Chartered Institute of Bankers of Nigeria (CIBN) and the Royal Bank of Canada (RBC).

Sun, J., \& Liu, G. (2011). Client-specific litigation risk and audit quality differentiation. Managerial Auditing Journal, 26(4), 300-316.

Taktak, N. B., \& Mbarki, I. (2014). Board characteristics, external auditing quality, and earnings management: Evidence from the Tunisian banks. Journal of Accounting in Emerging Economies, 4(1), 79-96.

Teoh, S. H., \& Wong, T. J. (1993). Perceived auditor quality and the earnings response coefficient. The Accounting Review, 68(2), 346-366.

Tsipouridou, M., \& Spathis, C. (2014). Audit opinion and earnings management: Evidence from Greece. Accounting Forum, $38(1), 38-54$.

Vander Bauwhede, H., \& Willekens, M. (2004). Evidence on (the lack of) audit-quality differentiation in the private client segment of the Belgian audit market. European Accounting Review, 13(3), 501-522.

Vichitsarawong, T., \& Pornupatham, S. (2015). Do audit opinions reflect earnings persistence? Managerial Auditing Journal, 30(3), 244-276.

Wahlen, J. M. (1994). The nature of information in commercial bank loan loss disclosures. The Accounting Review, 69(3), 455-478. 